\title{
Thermodynamic Analysis and Synthesis Gas Generation by Chemical-Looping Gasification of Biomass with Nature Hematite as Oxygen Carriers*
}

\author{
Zhen Huang, Fang He, Anqing Zheng, Kun Zhao, Sheng Chang, Xinai Li, Haibin Li, Zengli Zhao \\ Key Laboratory of Renewable Energy and Gas Hydrate of Chinese Academy of Sciences, \\ Guangzhou Institute of Energy Conversion, Chinese Academy of Sciences, Guangzhou, China \\ Email: hefang@ms.giec.ac.cn
}

Received January 24, 2013; revised February 28, 2013; accepted March 8, 2013

\begin{abstract}
Thermodynamic parameters of chemical reactions in the system were carried out through thermodynamic analysis. According to the Gibbs free energy minimization principle of the system, equilibrium composition of the reactions of chemical-looping gasification (CLG) of biomass with natural hematite $\left(\mathrm{Fe}_{2} \mathrm{O}_{3}\right)$ as oxygen carrier were analyzed using commercial software of HSC Chemistry 5.1. The feasibility of the CLG of biomass with hematite was experimental verified in a lab-scale bubbling fluidized bed reactor using argon as fluidizing gas. It was indicated the experimental results were consistent with the theoretical analysis. The presence of oxygen carrier gave a significant effect on the biomass conversion and improved the synthesis gas yield obviously. It was observed that the gas content of $\mathrm{CO}$ and $\mathrm{H}_{2}$ was over $70 \%$ in CLG of biomass. The reduced hematite particles mainly existed in form of $\mathrm{FeO}$. It was showed that the reduction of natural hematite with biomass proceeds in a stepwise manner from $\mathrm{Fe}_{2} \mathrm{O}_{3} \rightarrow \mathrm{Fe}_{3} \mathrm{O}_{4} \rightarrow \mathrm{FeO}$. Reduction product of natural hematite can be restored the lattice oxygen by oxidation with air.
\end{abstract}

Keywords: Thermodynamics; Synthesis Gas; Natural Hematite; Oxygen Carriers; Biomass Chemical Looping Gasification

\section{Introduction}

Chemical-looping gasification (CLG) is a novel gasification technique that involves the use of oxygen carrier, which transfers oxygen from air to the fuel, which is partially oxidized into $\mathrm{H}_{2}$ and $\mathrm{CO}$, avoiding the direct contact between them. Therefore, the air to fuel ratio is kept low to prevent the fuel from becoming fully oxidized to $\mathrm{CO}_{2}$ and $\mathrm{H}_{2} \mathrm{O}$. [1]. A basic chemical-looping gasification system has two reactors, one for air and one for fuel, as is illustrated in Figure 1. On the contrast of traditional gasification technologies, CLG has several potential benefits as follows [2]. Firstly, the recycling of oxygen carrier can provide the oxygen needed for gasification, thus, it can save the cost for making pure oxygen. Secondly, the oxidation reaction of the metal oxide is very exothermic; however, the reduction reactions are endothermic. So, the heat for the endothermic reduction reactions is given by the circulating solids coming from the air

\footnotetext{
"Project supported by Natural Science Foundation of China (No 51076154), Guangdong Provincial Science \& Technology Research Foundation (2010B010900047) and "12th Five Years" National Science and Technology Support Program (2011BAD15B05).
}

reactor at higher temperature. And the same time, the oxygen carrier also can catalyze tar cracking, which reduced the content of tar in biomass gasification [3-5].

There are some works studying chemical looping gasification of solid fuels. He et al. [6] investigated the CLG of biomass with natural hematite as oxygen carriers in a bubbling fluidized bed reactor. It was found that the gasification efficiency and carbon conversion reached up to $75.8 \%$ and $94 \%$, respectively. Cao et al. [7] tested in circulating fluidized bed reactor different oxygen carriers, which can capture that the concentration of $\mathrm{CO}_{2}$ enriched to $99 \%$. B. Acharya et al. [8] put forward a set of system which produced hydrogen through biomass chemicallooping gasification. Efficiency of the system was as high as $87.49 \%$, and the hydrogen concentration was found to be $71 \%$, in addition, zero discharge of $\mathrm{CO}_{2}$ can realize.

The objective of this investigation was to explore the possibility of using natural hematite $\left(\mathrm{Fe}_{2} \mathrm{O}_{3}\right)$ as the oxygen carrier in CLG of biomass. In the present work, the thermodynamics of biomass chemical looping gasification was analyzed, and the same time, CLG of biomass with natural hematite as oxygen carrier was experimen- 


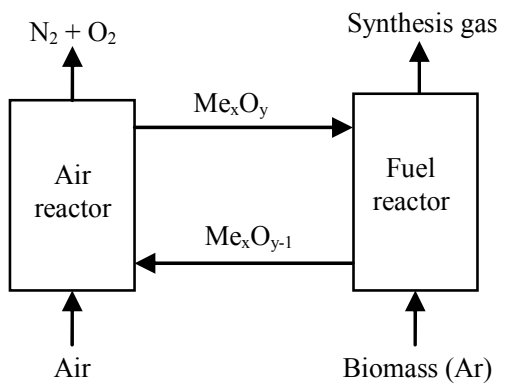

Figure 1. Chemical-looping gasification of biomass with oxygen carrier.

tally investigated in a lab-scale bubbling fluidized bed reactor using argon as fluidizing gas.

\section{Thermodynamic Analysis of Chemical-Looping Gasfication}

\subsection{Chemical Reactions}

$\mathrm{Fe}_{2} \mathrm{O}_{3}$ as oxygen carriers in the air reactor, the main reactions at $750^{\circ} \mathrm{C}$ probably are:

$$
\begin{gathered}
4 \mathrm{Fe}_{3} \mathrm{O}_{4}+\mathrm{O}_{2} \rightarrow 6 \mathrm{Fe}_{2} \mathrm{O}_{3} \\
\Delta H=-483.07 \mathrm{~kJ} / \mathrm{mol} \\
4 \mathrm{FeO}+\mathrm{O}_{2} \rightarrow 2 \mathrm{Fe}_{2} \mathrm{O}_{3} \\
\Delta H=-554.68 \mathrm{~kJ} / \mathrm{mol}
\end{gathered}
$$

In the fuel reactor, the main reactions probably are: pyrolysis of biomass:

$$
\begin{gathered}
\mathrm{C}_{\mathrm{n}} \mathrm{H}_{2 \mathrm{~m}} \mathrm{O}_{\mathrm{x}} \rightarrow \text { char }+ \text { tar + syngas } \\
\left(\mathrm{CO}, \mathrm{H}_{2}, \mathrm{CO}_{2}, \mathrm{CH}_{4}\right)
\end{gathered}
$$

The reduction reactions of oxygen carrier particle with pyrolytic products of biomass at $650^{\circ} \mathrm{C}$ [9]

$$
\begin{gathered}
\mathrm{CO}+3 \mathrm{Fe}_{2} \mathrm{O}_{3} \rightarrow \mathrm{CO}_{2}+2 \mathrm{Fe}_{3} \mathrm{O}_{4} \\
\Delta \mathrm{H}=-37.67 \mathrm{~kJ} / \mathrm{mol} \\
\mathrm{CO}+\mathrm{Fe}_{2} \mathrm{O}_{3} \rightarrow \mathrm{CO}_{2}+2 \mathrm{FeO} \\
\Delta H=-3.22 \mathrm{~kJ} / \mathrm{mol} \\
\mathrm{H}_{2}+3 \mathrm{Fe}_{2} \mathrm{O}_{3} \rightarrow \mathrm{H}_{2} \mathrm{O}+2 \mathrm{Fe}_{3} \mathrm{O}_{4} \\
\Delta H=-2.01 \mathrm{~kJ} / \mathrm{mol} \\
\mathrm{H}_{2}+\mathrm{Fe}_{2} \mathrm{O}_{3} \rightarrow \mathrm{H}_{2} \mathrm{O}+2 \mathrm{FeO} \\
\Delta H=32.44 \mathrm{~kJ} / \mathrm{mol} \\
\mathrm{CH}_{4}+3 \mathrm{Fe}_{2} \mathrm{O}_{3} \rightarrow 2 \mathrm{H}_{2}+\mathrm{CO}+2 \mathrm{Fe}_{3} \mathrm{O}_{4} \\
\Delta H=221.76 \mathrm{~kJ} / \mathrm{mol} \\
\mathrm{CH}_{4}+4 \mathrm{Fe}_{2} \mathrm{O}_{3} \rightarrow 2 \mathrm{H}_{2} \mathrm{O}+\mathrm{CO}_{2}+8 \mathrm{FeO} \\
\Delta H=317.87 \mathrm{~kJ} / \mathrm{mol} \\
\mathrm{C}+3 \mathrm{Fe}_{2} \mathrm{O}_{3} \rightarrow \mathrm{CO}+2 \mathrm{Fe}_{3} \mathrm{O}_{4} \\
\Delta H=133.65 \mathrm{~kJ} / \mathrm{mol}
\end{gathered}
$$

$$
\begin{gathered}
\mathrm{C}+2 \mathrm{Fe}_{2} \mathrm{O}_{3} \rightarrow \mathrm{CO}_{2}+4 \mathrm{FeO} \\
\Delta H=164.88 \mathrm{~kJ} / \mathrm{mol}
\end{gathered}
$$

Therefore, in the presence of oxygen carriers, these reactions occur sequentially and simultaneously during biomass pyrolysis and gasification. The final products of biomass gasification are determined by the interaction of a couple of above mentioned reactions.

\subsection{Thermodynamic Analysis of Gasification Process}

Effect of the temperature on the Gibbs free energy $(\Delta r G)$ and chemical equilibrium constant (Logk) of reactions (4)-(11) was shown in Figure 2. In Figure 2, it found that the $\Delta r G$ is less than zero and the Logk is more than zero, which means that the reactions (4)-(11) can react in the thermodynamics. If dividing the reactions (4)-(11) into four groups, that is (4)-(5); (6)-(7); (8)-(9); (10)-(11), it can be seen that the former is less than the later for $\Delta r G$, but the trend of Logk is opposite from the Figure 2, further, the trends of change increased with the increase of temperature. As we known, if the smaller $\Delta r G$ and the greater Logk, the reaction will be easier to occur. So, it can conclude that oxygen carriers were reduced gradually in the atmosphere of biomass pyrolysis. It meant the oxygen carriers changed as follows: $\mathrm{Fe}_{2} \mathrm{O}_{3} \rightarrow \mathrm{Fe}_{3} \mathrm{O}_{4} \rightarrow$ $\mathrm{FeO}$.

\subsection{Chemical Equilibrium of Biomass Gasification Process}

There were a number of reactions in the CLG according to the theory analysis. However, some reactions were predominant and the other reactions were secondary in the actual process. If the secondary reactions were ignored, it can help us a better understanding of the CLG. According to the principle of Gibbs free energy minimization, equilibrium components of biomass with $\mathrm{Fe}_{2} \mathrm{O}_{3}$

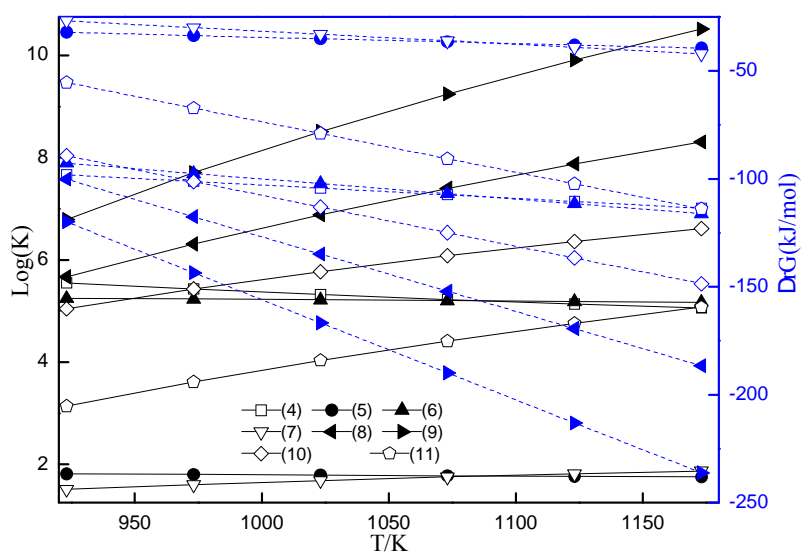

Figure 2. Effects of temperature on $\Delta r G$ and $\log K$ of reaction (4)-(11). 
were investigated through HSC Chemistry 5.1 software, which is a produced by Outokumpu company in Finland. The approximate formula of biomass is $\mathrm{CH}_{1.34} \mathrm{O}_{0.65}$, regardless the $\mathrm{S}$ and $\mathrm{N}$.

In order to illustrate the influence of the biomass to $\mathrm{Fe}_{2} \mathrm{O}_{3}$ ratio on equilibrium composition, the equilibrium composition was calculated by changing $\mathrm{Fe}_{2} \mathrm{O}_{3}$ content at the same temperature. The result was shown in Figure 3. The temperature is set at $750^{\circ} \mathrm{C}$ and the initial value of $\mathrm{CH}_{1.34} \mathrm{O}_{0.65}$ is $1 \mathrm{kmol}$ in the process. In Figure 3(a), the $\mathrm{Fe}_{2} \mathrm{O}_{3}$ content was gradually increased from $0.02 \mathrm{kmol}$ to $6 \mathrm{kmol}$. As seen in figure, the content of incomplete oxidation products $\left(\mathrm{CO}+\mathrm{H}_{2}\right)$ gradually decreased and the content of complete oxidation products $\left(\mathrm{CO}_{2}+\mathrm{H}_{2}\right)$ gradually increased with the amount of $\mathrm{Fe}_{2} \mathrm{O}_{3}$ gradually increased, respectively. As the amount of $\mathrm{Fe}_{2} \mathrm{O}_{3}$ is nearly $5 \mathrm{kmol}$, the amount of $\mathrm{H}_{2}+\mathrm{CO}$ is almost zero, and the content of $\mathrm{H}_{2} \mathrm{O}+\mathrm{CO}_{2}$ is almost constantly. At the same time, the amount of carbon which produced by carbon deposit reaction decreased with increase the amount of $\mathrm{Fe}_{2} \mathrm{O}_{3}$, the carbon is almost disappeared as the $\mathrm{Fe}_{2} \mathrm{O}_{3}$ content near $1 \mathrm{kmol}$. It can be observed the reduction products of $\mathrm{Fe}_{2} \mathrm{O}_{3}$ are mainly $\mathrm{FeO}$ and $\mathrm{Fe}_{3} \mathrm{O}_{4}$. As the amount of $\mathrm{Fe}_{2} \mathrm{O}_{3}$ is less than $3.5 \mathrm{kmol}$, the main reduction product is $\mathrm{FeO}$, however, the main reduction product is $\mathrm{Fe}_{3} \mathrm{O}_{4}$ when the amount of $\mathrm{Fe}_{2} \mathrm{O}_{3}$ is more than 3.5 kmol. In this paper, it concerned to produce syngas which is mainly composed of $\mathrm{H}_{2}$ and $\mathrm{CO}$. Thus, in order to obtain syngas instead of $\mathrm{CO}_{2}$ and water, it is necessary to keep the ratio of lattice oxygen to fuel as low as to prevent the fuel from being fully oxidized to $\mathrm{CO}_{2}$ and $\mathrm{H}_{2} \mathrm{O}$. The effect of the amount of $\mathrm{Fe}_{2} \mathrm{O}_{3}$ from 0.02 to 1.2 $\mathrm{kmol}$ on the equilibrium composition is shown in detail in Figure 3(b). As shown in the figure, the amount of $\mathrm{CO}$ reaches maximum when the $\mathrm{Fe}_{2} \mathrm{O}_{3}$ content is about $0.2 \mathrm{kmol}$, and then which is declined gradually with the amount of $\mathrm{Fe}_{2} \mathrm{O}_{3}$ increasing. It is worth to note that the amount of $\mathrm{CO}_{2}$ is more than $\mathrm{CO}$ as the $\mathrm{Fe}_{2} \mathrm{O}_{3}$ content is more than $0.7 \mathrm{kmol}$, which means that biomass is completely oxidized due to the lattice oxygen increasing. So, it can produce more $\mathrm{CO}_{2}$ rather than $\mathrm{CO}$. Therefore, the amount of $\mathrm{Fe}_{2} \mathrm{O}_{3}$ must be kept between $0.2 \mathrm{kmol}$ and 0.7 $\mathrm{kmol}$ to obtain the syngas. The reduction product of $\mathrm{Fe}_{2} \mathrm{O}_{3}$ is mainly $\mathrm{FeO}$, and almost nonexistent $\mathrm{Fe}_{3} \mathrm{O}_{4}$. At the same time, it can infer that carbon deposition was caused by material excessive from the Figure 3.

According to the analysis of the thermodynamic theories, it can obtain the synthesis gas which the main component is $\mathrm{CO}$ and $\mathrm{H}_{2}$ through the ratio of fuel to lattice oxygen is kept low level. Meanwhile, the main reduction product of $\mathrm{Fe}_{2} \mathrm{O}_{3}$ is $\mathrm{FeO}$.

In the next work, CLG of biomass with natural hematite as oxygen carrier was experimentally studied in a lab-scale bubbling fluidized bed reactor using argon as

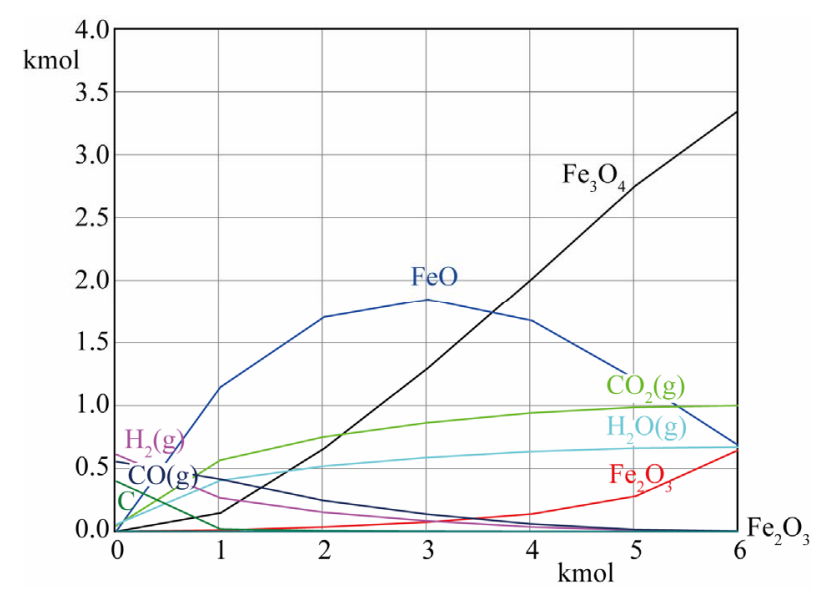

(a)

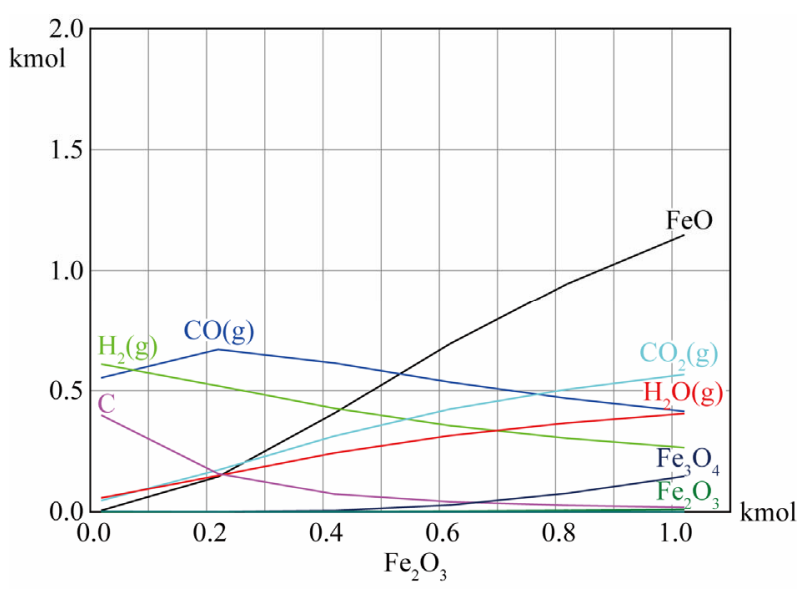

(b)

Figure 3. Effects of $\mathrm{Fe}_{2} \mathrm{O}_{3}$ on equilibrium composition at $750^{\circ} \mathrm{C}$.

fluidized gas.

\section{Experimental}

\subsection{Raw Materials}

The sawdust of pine with particle sizes between 250 $425 \mu \mathrm{m}$ was dried in the oven which kept $105^{\circ} \mathrm{C}$. The dry-basis proximate analysis and ultimate analysis of the sawdust are showed in Table 1. The hematite with particle sizes between $180-250 \mu \mathrm{m}$ which was supplied by Guangdong Iron \& Steel Group Co. Ltd. The elements composition analysis of the hematite is presented in Table 2. According to the $\mathrm{Fe}^{3+}$ fraction, it is calculated that the $\mathrm{Fe}_{2} \mathrm{O}_{3}$ content is about $81.66 \%$ in the hematite.

\subsection{Laboratory Setup}

The experiments were conducted with a bubbling fluidized bed reactor of quartz placed in a transparent furnace, as is illustrated in Figure 4. The reactor is in length of $1000 \mathrm{~mm}$ and an inner diameter of $60 \mathrm{~mm}$. The bed tem- 
Table 1. Proximate and ultimate analysis of pine.

\begin{tabular}{|c|c|c|c|c|c|c|c|c|c|}
\hline \multicolumn{4}{|c|}{ Proximate analysis wad \% } & \multicolumn{5}{|c|}{ Ultimate analysis wad \% } & \multirow{2}{*}{$\mathrm{Q}_{\mathrm{av}} \mathrm{KJ} / \mathrm{kg}$} \\
\hline M & $\mathrm{V}$ & $\mathrm{FC}$ & A & $\mathrm{C}$ & $\mathrm{H}$ & $\mathrm{O}^{*}$ & $\mathrm{~N}$ & S & \\
\hline 8.39 & 84.31 & 6.88 & 0.42 & 49.66 & 5.55 & 43.33 & 0.021 & 1.44 & 18506 \\
\hline
\end{tabular}

*: by difference.

Table 2. Elements composition analysis of iron ore (\%).

\begin{tabular}{cccccc}
\hline Item & $\mathrm{S}$ & $\mathrm{Fe}^{3+}$ & $\mathrm{Fe}^{2+}$ & $\mathrm{SiO}_{2}$ & $\mathrm{Al}_{2} \mathrm{O}_{3}$ \\
Content & 0.031 & 57.16 & 0.41 & 5.64 & 0.88 \\
\hline Item & $\mathrm{CaO}$ & $\mathrm{MgO}$ & $\mathrm{Na}_{2} \mathrm{O}$ & $\mathrm{K}_{2} \mathrm{O}$ & $\mathrm{P}$ \\
Content & 0.24 & 0.035 & 0.10 & 0.048 & 0.017 \\
\hline
\end{tabular}

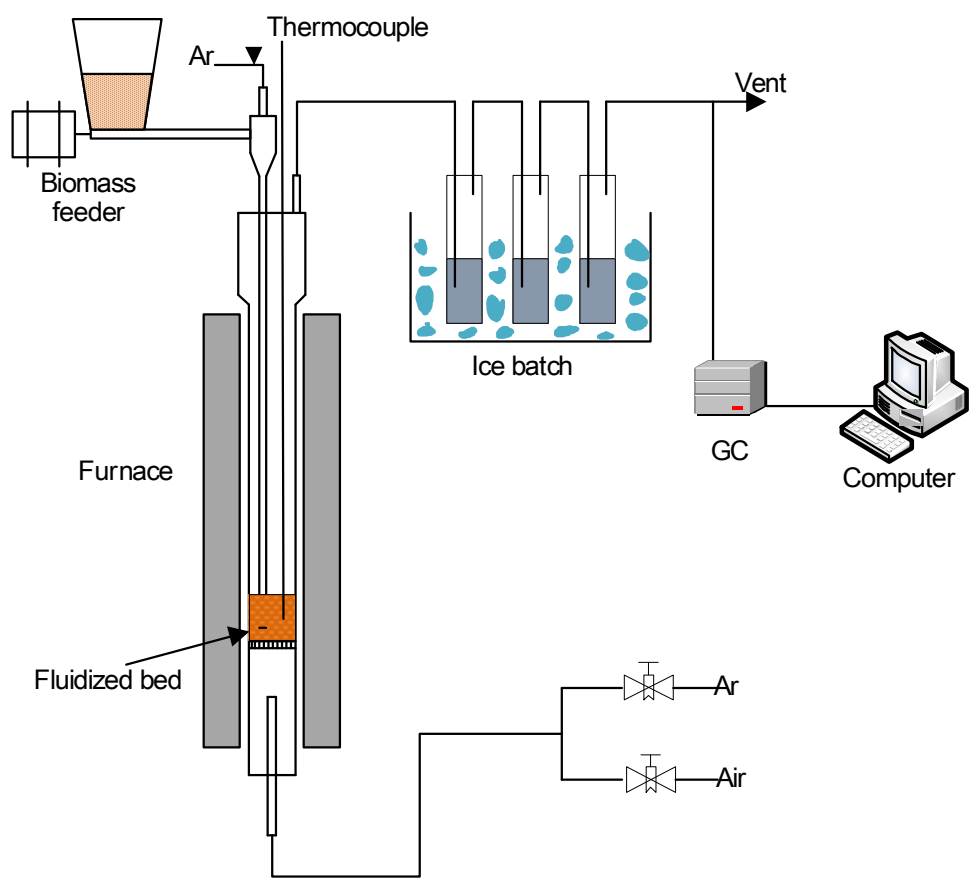

Figure 4. Schematic layout of the laboratory setup.

perature was measured $5 \mathrm{~mm}$ above the porous quartz plate using a K-type thermocouple. Oxygen carrier particles were placed on the porous plate and were then heated in air flow to set temperature. During the reducing period, the fluidizing gas was argon $(800 \mathrm{~L} / \mathrm{hr})$, which was introduced from the bottom of the reactor. When the temperature comes to the set value, biomass was continuously fed (by a screw feeder) in a hopper at the top of the reactor. At the same time, $\operatorname{argon}(200 \mathrm{~L} / \mathrm{hr})$ was introduced from the top of the hopper. Therefore, the biomass sample was pushed by argon flow into the fluidized bed through a drop tube. The flue gases are passed through the cold trap to collect solid particles, water, and tar then introduced into the sampling bag. The composition of the gas products is measured using a gas chro- matograph (SHIMADZUA Gas Chromatograph, GC-20B). All the oxygen carrier samples were performed with an X-Ray Diffraction (X'Pert PRO XRD).

\section{Results and Discussion}

\subsection{Effect of the Presence of Hematite Particles on the Biomass Gasification}

Based on the thermodynamic analysis, the mass of oxygen carriers and biomass material were set to $150 \mathrm{~g}$ and $44 \mathrm{~g}$ in a single test, respectively. The ratio of lattice oxygen to fuel is 0.42 .

The effect of the presence of hematite particles on the CLG of biomass was investigated at temperatures of $750^{\circ} \mathrm{C}$. Figure 5 shows the comparison of the gas yields 

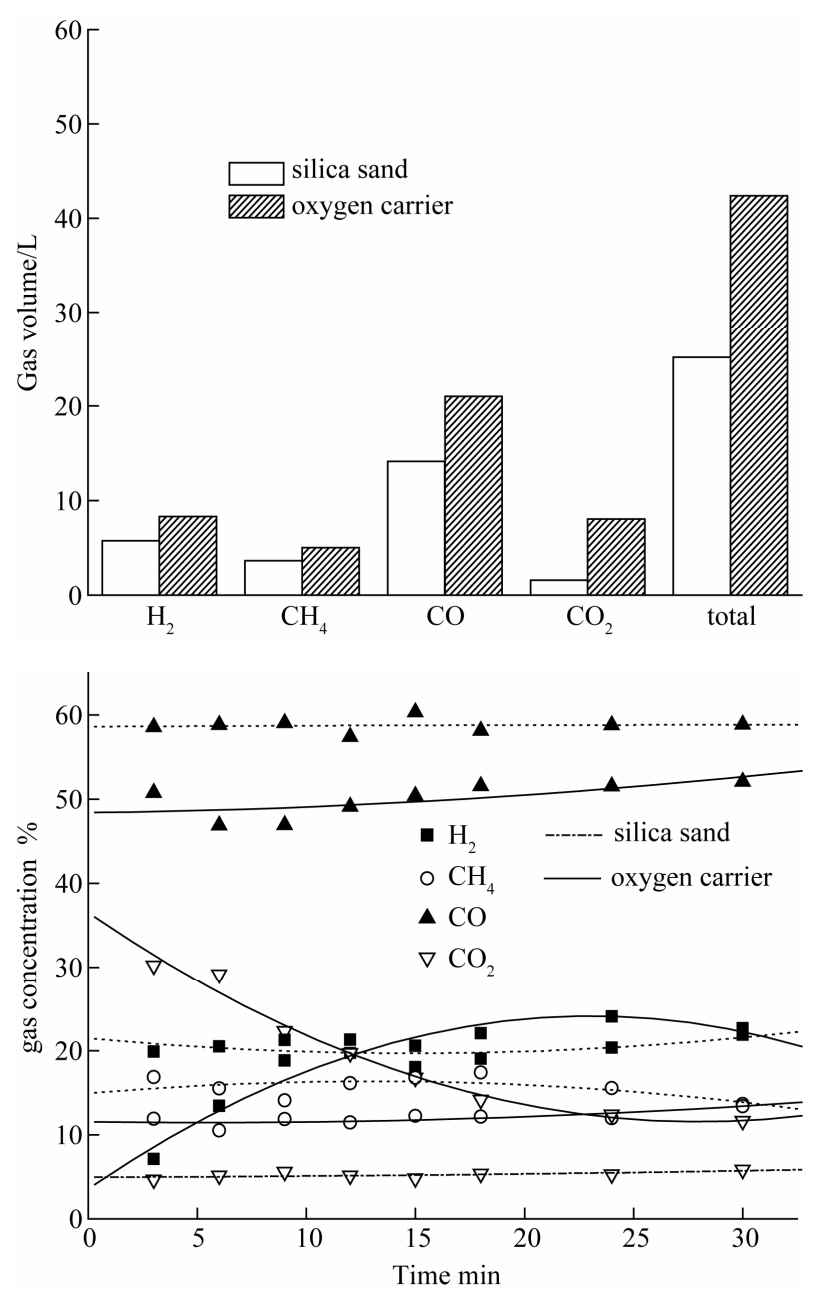

Figure 5. The effect of oxygen carrier on CLG of biomass at $750^{\circ} \mathrm{C}$.

of each gaseous component and the sum of the yields of $\mathrm{H}_{2}, \mathrm{CH}_{4}, \mathrm{CO}$ and $\mathrm{CO}_{2}$ in the process of biomass CLG with those of blank tests during testing period of $30 \mathrm{~min}$. In the blank tests, the hematite particles were replaced by silica sand. Therefore, the process taking place in the blank tests is only pyrolysis rather than CLG of biomass. As shown in Figure 5, the volume yields of each gaseous constituent were obviously enlarged in the presence of hematite particles. The total gas yields were increased from $25.17 \mathrm{~L}$ up to $42.39 \mathrm{~L}$ at $750^{\circ} \mathrm{C}$. The yields of the generated gases $\left(\mathrm{H}_{2}, \mathrm{CH}_{4}, \mathrm{CO}\right.$, and $\left.\mathrm{CO}_{2}\right)$ obtained with hematite particles were apparently larger than with silica sand, which suggest that the lattice oxygen in the hematite particles was used as the gasifying agent during biomass gasification. The main components of gaseous product are $\mathrm{CO}$ and $\mathrm{H}_{2}$ which reached about $70 \%$ amount of the total volume of the gaseous product. The promoter action of lattice oxygen to carbon conversion was more obvious than to hydrogen conversion. So, the carbon can convert into carbon dioxide and carbon monoxide more completely, it can cause the volume of gaseous product which contained carbon element going up obviously, especially the volume of carbon dioxide. Figure 5 also illustrates gas concentrations (on the basis of argon free) of biomass gasification with oxygen carrier and pyrolysis with silica sand during $30 \mathrm{~min}$ at $750^{\circ} \mathrm{C}$. Clearly, it was found that the concentrations of $\mathrm{H}_{2}, \mathrm{CH}_{4}, \mathrm{CO}$ and $\mathrm{CO}_{2}$ were kept stable when biomass was pyrolyzed with inert silica sand. Whereas, there were significant changes for the gaseous concentration of biomass with hematite particles as reaction time increasing, especially the concentration of $\mathrm{CO}_{2}$ and $\mathrm{H}_{2}$. The $\mathrm{CO}$ and $\mathrm{CH}_{4}$ concentrations of biomass with hematite particles were both lower than those of biomass with silica sand. $\mathrm{H}_{2}$ concentration increased with the reaction time going on in the CLG of biomass probably owing to a part of biomass was totally oxidized into $\mathrm{CO}_{2}$ and $\mathrm{H}_{2} \mathrm{O}$ which subsequently accelerated the hydrogen generation reactions taking place rightward. In addition, in the initial stage of biomass gasification with hematite particles, the $\mathrm{CO}_{2}$ fraction was more than $30 \%$ in the generated gas due to the easily availability of active lattice oxygen in the oxygen carrier particles. As the reactions proceeded, the concentration of $\mathrm{CO}_{2}$ decreased gradually to $10 \%$ approximately. These results may be contributed to the amount of valid hematite particles decreasing with the reactions proceeding. So, portion of biomass taken out by fluidized gas after only pyrolytic reaction, which can cause the proportion of pyrolysis gas increasing in the gaseous products. Through the contrast test, it experimental verified the feasibility of biomass chemical-looping gasification with hematite particles as oxygen carriers.

\subsection{XRD Analysis of Oxygen Carriers}

Figure 6 shows the XRD patterns of fresh oxygen carrier, the oxidized oxygen carrier with the air, and the reduced oxygen carrier of the fuel reactor under different temperature, respectively. In Figure 6(b), it can be seen that the mainly existed in form of $\mathrm{Fe}_{2} \mathrm{O}_{3}$ and $\mathrm{SiO}_{2}$ for fresh oxygen carriers. Comparison to fresh oxygen carrier, there was no chemical changes occurred in the regeneration of reacted oxygen carrier, and $\mathrm{Fe}_{2} \mathrm{O}_{3}$ was found the major phase with minor amounts of $\mathrm{Fe}_{3} \mathrm{O}_{4}$. The forms of oxygen carriers after the reduction reaction changed as temperature rising, as seen in Figure 6(a), at lower temperature $\left(650^{\circ} \mathrm{C}\right)$, the variation of oxygen carriers was from $\mathrm{Fe}_{2} \mathrm{O}_{3}$ to $\mathrm{Fe}_{3} \mathrm{O}_{4}$, the main existence form of reduced oxygen carriers was $\mathrm{FeO}$ at higher temperature $\left(\geq 750^{\circ} \mathrm{C}\right)$.

However, the variation of hematite particles as oxygen carriers was from $\mathrm{Fe}_{2} \mathrm{O}_{3}$ to $\mathrm{Fe}_{3} \mathrm{O}_{4}$ in the CLC of biomass [10-12].

The elements content of $\mathrm{Fe}$ in hematite particles was analyzed as shown in Figure 7, it found that the ferric 


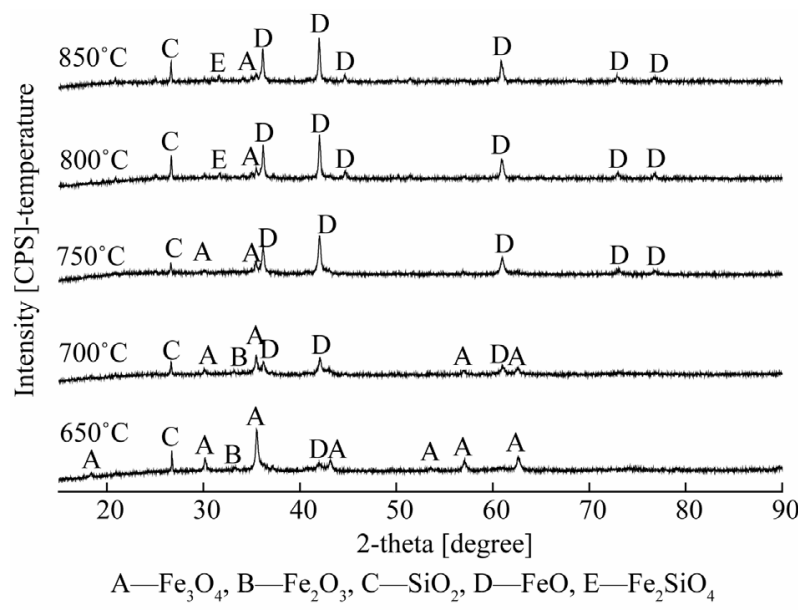

(a)

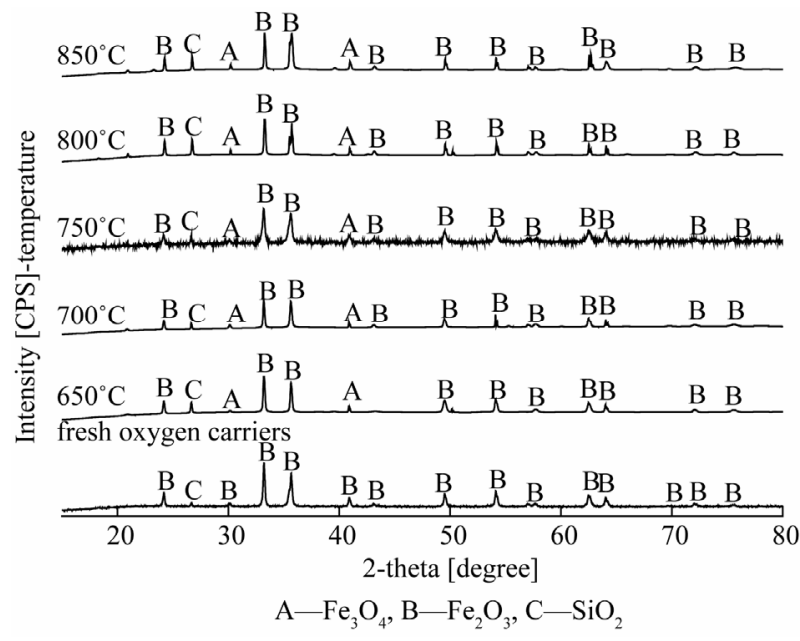

(b)

Figure 6. XRD patterns of fresh and reacted hematite particles at different temperatures. (a) Reduction; (b) Oxidization.

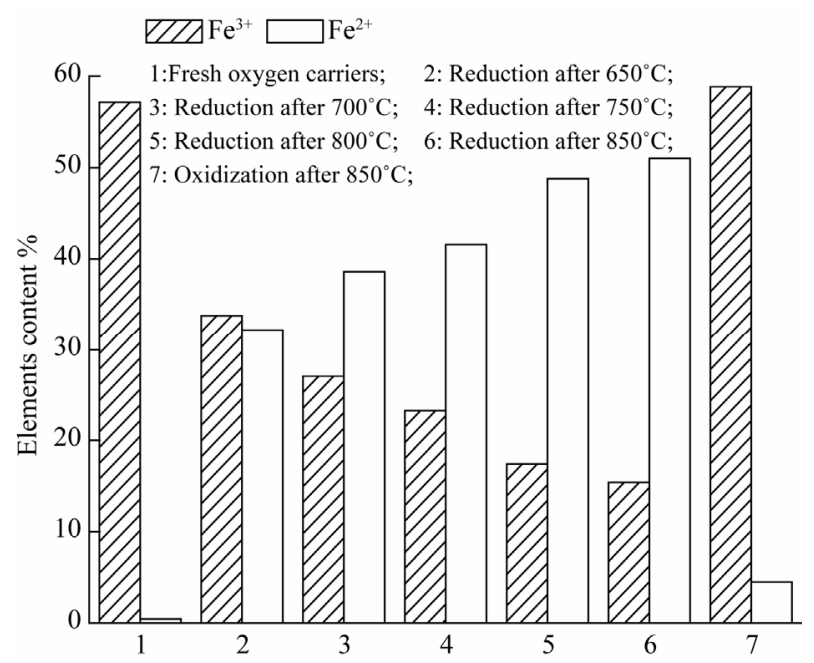

Figure 7. Elements composition analysis of hematite particles. iron was reduced to ferrous iron in the CLG of biomass. The tendency of conversion was more and more obviously with increase of temperature. The capacity of lattice oxygen in oxygen carriers was recovered by air oxidization, which was affected slightly on the reduction temperature. So, it is feasible that the hematite particles can be used circularly as oxygen carriers in the CLG of biomass, which have higher oxygen transfer ability.

According to the analysis of existence form of reduced oxygen carriers, it found that hematite particles undergone the process of biomass gasification as oxygen carriers, and the mainly existence form of hematite particles were $\mathrm{FeO}$ after reduction as the temperature higher than $750^{\circ} \mathrm{C}$. Further, the reduction of hematite particles with biomass proceeded in a stepwise manner from $\mathrm{Fe}_{2} \mathrm{O}_{3} \rightarrow$ $\mathrm{Fe}_{3} \mathrm{O}_{4} \rightarrow \mathrm{FeO}$. So, the main reactions were (2), (5), (7), (9), and (11) in the CLG of biomass with the hematite particles as oxygen carriers.

\section{Conclusion}

The process in CLG of biomass mixed with natural hematite as oxygen carriers was analyzed using the theory of thermodynamics, and then, the verification test was studied in a bubbling fluidized bed reactor with argon as fluidizing gas. It was found that the theory analysis was coincidence with the results of experiment. Consequently, it is feasibility natural hematite as oxygen carriers in CLG of biomass. It can obtain synthesis gas which mainly included $\mathrm{CO}$ and $\mathrm{H}_{2}$ by limiting the ratio of lattice oxygen to fuel between 0.2 and 0.7 . The presence of oxygen carriers could obviously affect the process of biomass thermal conversion, which can significantly increase gas yield and carbon conversion rate. The main components of gaseous product were $\mathrm{CO}$ and $\mathrm{H}_{2}$ which reached about $70 \%$ amount of the total volume of the gaseous product. The concentration of $\mathrm{CO}$ was the highest and the concentration of $\mathrm{CH}_{4}$ was the lowest during the biomass gasification. In addition, the concentrations of $\mathrm{H}_{2}, \mathrm{CO}$, and $\mathrm{CH}_{4}$ in the product gas slowly increased with the reaction proceeding, and the $\mathrm{CO}_{2}$ concentration showed an opposite trend. XRD analysis showed that the iron element in the reduced hematite particles mainly existed in form of $\mathrm{FeO}$, with minor formation of $\mathrm{Fe}_{3} \mathrm{O}_{4}$. Further, the lattice oxygen released, corresponding to the transformation $\mathrm{Fe}_{2} \mathrm{O}_{3} \rightarrow \mathrm{Fe}_{3} \mathrm{O}_{4} \rightarrow \mathrm{FeO}$, provided the oxygen element needed in biomass gasification. The capacity of lattice oxygen in reduced oxygen carriers can be recovered through air oxidization.

\section{Acknowledgements}

The financial support of National Natural Science Foundation of China (51076154) is gratefully acknowledged. This work was also supported by Science and Technol- 
ogy Project of Guangdong (2010B010900047), “12th Five Years" National Science and Technology Support Program (2011BAD15B05).

\section{REFERENCES}

[1] J. Bolhar-Nordenkampf, T. Proll, P. Kolbitsch, et al., "Performance of a NiO-Based Oxygen Carrier for Chemical Looping Combustion and Reforming in a $120 \mathrm{~kW}$ Unit," Energy Procedia, Vol. 1, No. 1, 2009, pp. 19-25. doi:10.1016/j.egypro.2009.01.005

[2] L. F. De Diego, M. Ortiz, F. Garcia-Labiano, et al., "Synthesis Gas Generation by Chemical-Looping Reforming Using a Nibased Oxygen Carrier," Energy Procedia, Vol. 1, No. 1, 2009, pp. 3-10. doi:10.1016/j.egypro.2009.01.003

[3] K. Tomishige, T. Kimura, J. Nishikawa, et al., "Promoting Effect of the Interaction between $\mathrm{Ni}$ and $\mathrm{CeO}_{2}$ on Steam Gasification of Biomass," Catalysis Communications, Vol. 8, No. 2, 2007, pp. 161-166.

[4] T. Nordgreen, T. Liliedahl and K. Sjostrom, "Metallic Iron as a Tar Breakdown Catalyst Related to Atmospheric, Fluidized Bed Gasification of Biomass," Fuel, Vol. 85, No. 5-6, 2006, pp. 689-694. doi:10.1016/j.fuel.2005.08.026

[5] C. Courson, E. Makaga, C. Petit, et al., "Development of Ni Catalysts for Gas Production from Biomass Gasification Reactivity in Steam and Dry Reforming," Catalysis Today, Vol. 63, No. 2, 2000, pp. 427-437. doi:10.1016/S0920-5861(00)00488-0

[6] F. He, Z. Huang, H. B. Li, et al., "Biomass Direct Chemi- cal Looping Conversion in a Fluidized Bed Reactor with Natural Hematite as an Oxygen Carrier," Proceedings of the 2011 Asia-Pacific Power and Energy Engineering Conference, Wuhan, 25-28 March 2011.

[7] Y. Cao and W.-P. Pan, "Investigation of Chemical Looping Combustion by Solid Fuels. 1. Process Analysis," Energy \& Fuels, Vol. 20, No. 5, 2006, pp. 1836-1844. doi:10.1021/ef050228d

[8] B. Acharya, A. Dutta and P. Basu, "Chemical-Looping Gasification of Biomass for Hydrogen-Enriched Gas Production with In-Process Carbon Dioxide Capture," Energy Fuel, Vol. 23, No. 10, 2009, pp. 5077-5083.

[9] A. Abad, J. Adanez, F. Garcia-Labiano, et al., "Mapping of the Range of Operational Conditions for $\mathrm{Cu}-, \mathrm{Fe}-$, and Ni-Based Oxygen Carriers in Chemical-Looping Combustion," Chemical Engineering Science, Vol. 62, No. 1-2, 2007, pp. 533-549. doi:10.1016/j.ces.2006.09.019

[10] L. H. Shen, J. H. Wu, J. Xiao, et al., "Chemical-Looping Combustion of Biomass in a $10 \mathrm{~kW}_{\text {th }}$ React or with Iron Oxide as an Oxygen Carrier," Energy and Fuels, Vol. 23, No. 5, 2009, pp. 2498-2505. doi:10.1021/ef900033n

[11] H. Leion, E. Jerndal, B. M. Steenari, et al., "Solid Fuels in Chemical-Looping Combustion Using Oxide Scale and Unprocessed Iron Ore as Oxygen Carriers," Fuel, Vol. 88, No. 10, 2009, pp. 1945-1954. doi:10.1016/j.fuel.2009.03.033

[12] A. Rubel, K. L. Liu, J. Neathery, et al., "Oxygen Carriers for Chemical Looping Combustion of Solid Fuels," Fuel, Vol. 88, No. 5, 2009, pp. 876-884. doi:10.1016/j.fuel.2008.11.006 